\title{
Analisis Optimalisasi Persediaan Barang Dengan Menggunakan Metode Economic Order Quantity Pada PT. Aneka usaha
}

\author{
Viona Afrilia1, Jemakmun² \\ 1Information System Departement, Bina Darma University, Palembang, Indonesia \\ 2Informatics Departement, Bina Darma University, Palembang, Indonesia \\ Email: 161410052@student.binadarma.ac.id ${ }^{1}$, jemakmun@binadarma.ac.id ${ }^{2}$
}

\begin{abstract}
Abstrak
PT. Aneka Usaha sebelumnya belum pernah menerapkan suatu metode untuk pengelolaan persediaan barang mereka dan hanya menggunakan perkiraanperkiraan saja. Hasil penelitian menunjukkan jika perhitungan menggunakan metode EOQ mampu menghemat biaya persediaan. Penghematan biaya yang didapatkan adalah untuk tahun 2017 terjadi penghematan biaya sebesar Rp.4.048.420, tahun 2018 sebesar Rp.4.833.344 dan 2019 sebesar Rp.6.865.523. Didapatkan 5 kali pemesanan dalam satu tahun dengan menggunakan metode EOQ. Perusahaan juga belum pernah menerapkan persediaan pengaman,dengan menggunakan perhitungan EOQ, hasil yang didapatkan menunjukkan persediaan pengaman untuk tahun 2017 sebesar 606 pcs, tahun 2018 sebesar 738 pcs dan 2019 sebesar 816 pcs. Karena sudah terbukti mengalami penghematan dengan metode EOQ sebaiknya perusahaan segera menggunakan metode EOQ untuk pengelolaan persediaan barang mereka kedepannya.
\end{abstract}

Kata Kunci: Persediaan, EOQ, Persediaan Pengaman, Pemesanan Kembali, Total Biaya Persediaan

\section{PENDAHULUAN}

Persediaan barang yang disimpan dalam gudang pada suatu perusahaan memiliki tujuan untuk memenuhi kebutuhan dalam proses kegiatan perusahaan. Dalam proses untuk mecapai tujuan perusahaan, akan dipengaruhi oleh faktor kelancaran produksi. Salah satu faktor dalam kelancaran proses produksi adalah pengendalian persediaan barang yang dilakukan dengan tepat. Agar pengelolaan persediaan seimbang maka harus dilakukan dengan lancar. Beban-beban biaya untuk penyimpanan dan penjagaan persediaan akan tinggi dan mengakibatkan terjadinya pemborosan jika persediaan di gudang terlalu besar (over stock) [1]. 
https://journal-computing.org/index.php/journal-cisa/index

PT. Aneka Usaha merupakan perusahaan yang bergerak di bidang distribusi . Produk yang didistribusikan oleh PT. Aneka Usaha adalah Popok Bayi dan Popok Dewasa, Sabun Mandi, Masker Wajah dan lain-lain. PT. Aneka Usaha masih masih menggunakan cara perkiraan manual dalam memasok barang,sehingga menyebabkan sering terjadinya over stock dan out of stock. Over stock disebabkan karena tidak adanya kepastian dalam jumlah barang yang harus didistribusikan ke retailer dan setiap bulannya PT. Aneka Usaha selalu menambah jumlah stock untuk di gudang. Ditambah lagi pengembalian produk dari retailer jika adanya produk yang rusak saat diterima mengakibatkan persediaan di gudang semakin menumpuk. Sedangkan out of stock disebabkan jika persediaan di gudang lebih sedikit daripada permintaan karena tidak adanya kepastian permintaan produk dari retailer.

Untuk kelancaran proses distribusi maka diperlukan pengelolaan dan pengendalian persediaan barang yang lebih efisien ,salah satu cara pengelolaan dan pengendalian persediaan barang yang banyak diterapkan adalah dengan menggunakan metode Economic Order Quantity. Economic Order Quantity (EOQ) merupakan suatu teknik pengadaan persediaan bahan baku pada suatu perusahaan yang menentukan berapa jumlah pemesanan yang ekonomis untuk setiap kali pemesanan dengan frekuensi yang telah ditentukan serta kapan dilakukan pemesanan kembali [2].

\section{METODOLOGI PENELITIAN}

\subsection{Optimalisai dan Persediaan Barang}

Optimalisasi adalah mencari alternatif dengan biaya yang paling efektif atau kinerja dicapai tertinggi menurut kendala yang diberikan, dengan memaksimalkan faktor yang diinginkan dan meminimalkan yang tidak diinginkan[3]. Sejumlah barang atau bahan yang disediakan perusahaan,yang berupa bahan mentah,barang jadi,maupun barang dalam proses yang digunakan perusahaan untuk memenuhi permintaan konsumen setiap waktu agar menjaga kelancaran proses produksi disebut dengan persediaan[4].

\subsection{Economic Order Quantity 1) Jumlah Pembelian Optimal}

Perhitungan Economic Order Quantity adalah sebagai berikut [5] : 


$$
E O Q=\frac{\sqrt{2 D S}}{H}
$$

Dimana:

$$
\begin{array}{ll}
E O Q & : \text { Kuantitas optimal } \\
D & : \text { Permintaan } \\
S & \text { : Biaya pemesanan } \\
H & \text { : Biaya penyimpanan }
\end{array}
$$

\section{2) Safety Stock}

Persediaan pengaman atau safety stock berfungsi untuk melindungi kesalahan dalam memprediksi permintaan selama lead time. Persediaan pengaman akan berfungsi apabila permintaan yang sesungguhnya lebih besar dari nilai rata-rata. Rumus safety stock dapat dilihat sebagai berikut [6]:

$$
S S=\text { Kebutuhan barang perhari } x L
$$

Dimana:

SS : Persediaan pengaman

$L \quad$ : Waktu tunggu untuk pengiriman

\section{3) Reorder Point}

Titik pemesanan ulang adalah titik kapan perusahaan harus melakukan pemesanan ulang dengan rumus sebagai berikut [5]:

$$
R O P=d \times L
$$

Dimana:

ROP : Titik pemesanan kembali

$d \quad$ : Permintaan perhari

L : Waktu tunggu antara pemesanan dan penerimaan barang. 


\section{4) Total Inventory Cost}

Total biaya pemesanan dan biaya penyimpanan adalah yang dimaksud dengan total biaya persediaan disini. Nilai Total Inventory Cost dapat diperoleh dengan persamaan berikut ini [5]:

$$
T I C=\sqrt{2 \cdot D \cdot S \cdot H}
$$

Dimana:

$D \quad$ : Permintaan tahunan dalam unit

$S \quad$ : Biaya pemesanan per tahun

$H \quad$ : Biaya penyimpanan per unit per tahun

\subsection{Jenis Penelitian}

Untuk penelitian ini metode yang digunakan merupakan metode deskriptif. Metode deskriptif ialah mengolah data dengan rumus-rumus statistik yang sudah disediakan, baik secara manual maupun dengan menggunakan komputer [7].

\subsection{Instrumen Penelitian}

Instrumen yang digunakan untuk memperoleh data yang akan digunakan dalam penelitian ini menggunakan wawancara sebagai instrumen penelitian terhadap PT. Aneka Usaha. Data yang diperoleh merupakan data sekunder berupa dokumentasi tertulis seperti:

1) Persediaan Popok

2) Pemakaian Popok

3) Pembelian Popok

4) Biaya penyimpanan Popok

5) Biaya pemesanan Popok

\subsection{Kerangka Pemikiran}

Konsep jalannya penelitian ini dimulai dengan mengidentifikasi hal-hal yang berkaitan dengan persediaan barang pada perusahaan dengan melihat bagaimana perusahaan selama ini mengendalikan persediaan dan bagaimana alur operasionalnya. Kemudian mengidentifikasi sistem pemesanan barang, pengiriman barang dan bagaimana barang keluar. 
Vol. 1, No. 2, May 2020 e-ISSN: 2775-2496

https://journal-computing.org/index.php/journal-cisa/index

Berikutnya analisis terhadap kondisi barang dilanjutkan dengan analisis perbandingan metode yang dilakukan perusahaan dengan metode $E O Q$. Berdasarkan uraian konsep diatas dibuat kerangka seperti berikut:

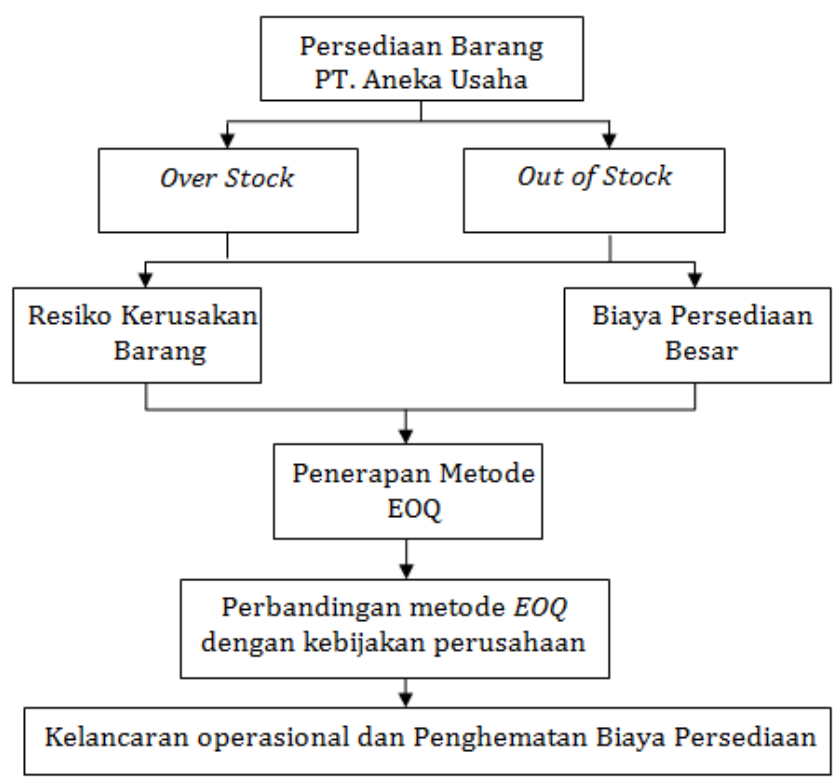

Gambar 1. Kerangka pemikiran

\section{HASIL DAN PEMBAHASAN}

\subsection{Data Pembelian Barang}

Grafik pembelian barang ditampilkan sebagai berikut:

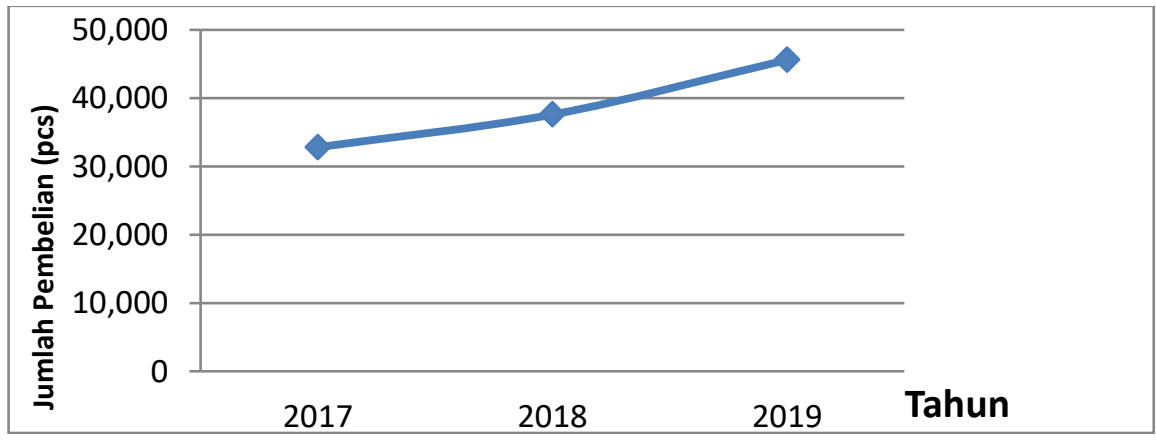

Gambar 2. Grafik pembelian 


\section{Journal of Computer and Information Systems Ampera}

Vol. 1, No. 2, May 2020 e-ISSN: 2775-2496

https://journal-computing.org/index.php/journal-cisa/index

Perusahaan melakukan pemesanan pada tahun 2017 sebesar 32.814 pcs, pada tahun 2018 sebesar 37.6000 pcs dan 2019 sebesar 45.600 pcs. Yang mana hal tersebut berarti terjadi peningkatan jumlah pembelian setiap tahunnya. Grafik sisa penjualan didapatkan sebagai berikut:

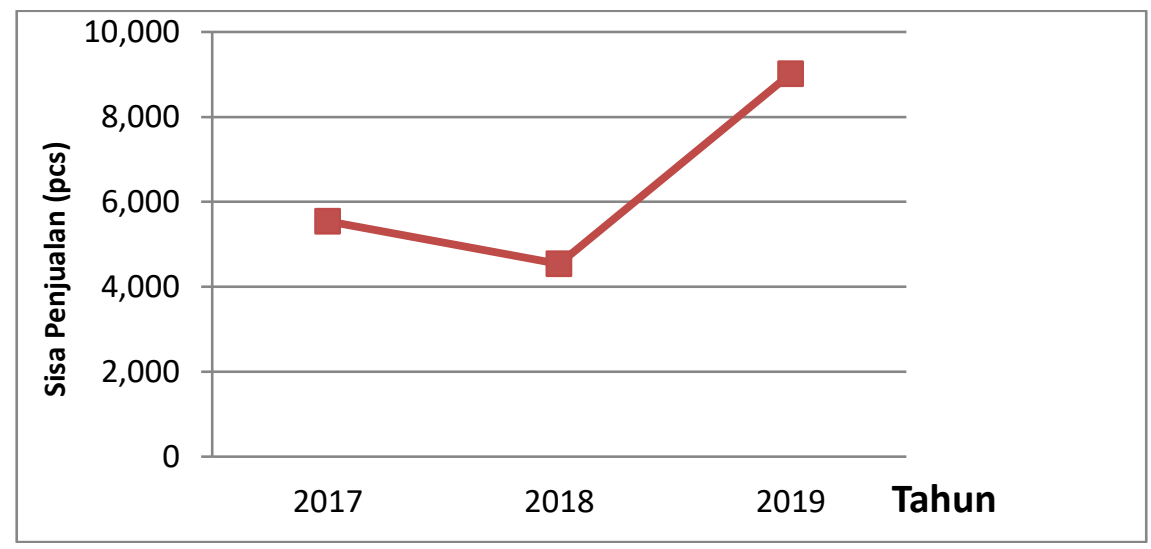

Gambar 3. Grafik sisa penjualan

Kelebihan barang pada tahun 2017 sebanyak 5.546 pcs, pada tahun 2018 terjadi penurunan sisa barang menjadi 4.534 pcs dan sisa barang terbanyak ada pada tahun 2019 yaitu sebesar 9.016 pcs.

\subsection{Perhitungan EOQ}

1) Tampilan VBA Macro Excel perhitungan metode $E O Q$

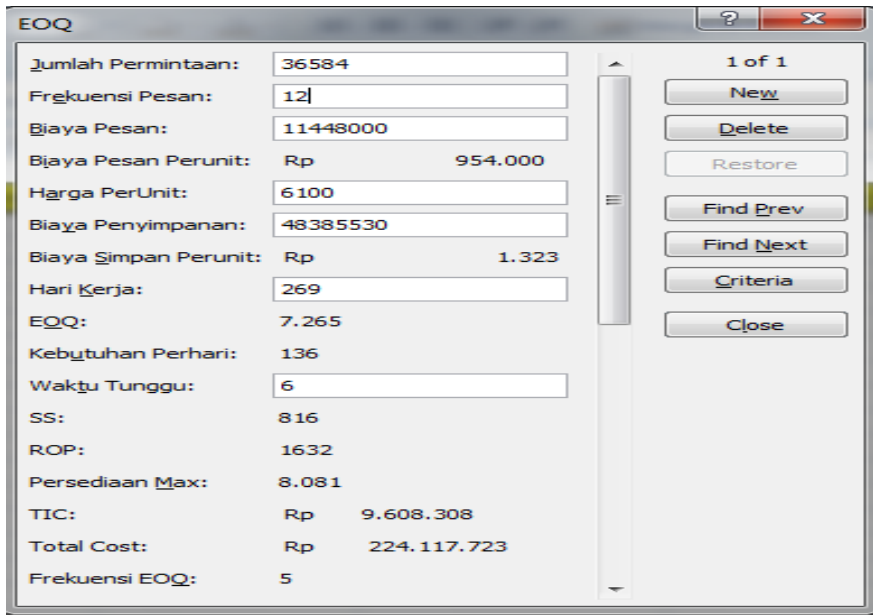

Gambar 4. Tampilan VBA Macro Excel 
Sistem ini dapat menghitung jumlah biaya pesan per produk, biaya simpan per produk, pembelian paling ekonomis, frekuensi pemesanan dalam satu tahun, jumlah persediaan pengaman, titik pemesanan kembali dan total biaya persediaan dengan tahapan mengisikan jumlah data sesuai dengan kolom yang telah tersedia.

2) Biaya Pesan dan Biaya Simpan

Biaya pemesanan mencakup seluruh biaya yang dikeluarkan saat melakukan pemesanan barang Pada PT. Aneka Usaha dari tahun 2017, 2018 hingga 2019. Biaya tersebut meliputi biaya pembuatan faktur dan biaya bongkar barang. Sedangkan Biaya penyimpanan yang dikeluarkan untuk seluruh proses penyimpanan barang didalam gudang dalam jangka waktu satu tahun.

Tabel 1. Biaya pemesanan

\begin{tabular}{lllll}
\hline No & \multicolumn{1}{c}{ Jenis Biaya } & \multicolumn{3}{c}{ Tahun } \\
\cline { 3 - 5 } & & \multicolumn{1}{c}{2018} & \multicolumn{1}{c}{2019} \\
\hline 1 & Biaya pembuatan faktur & Rp.3.600.000 & Rp.4.200.000 & Rp.5.448.000 \\
2 & Biaya bongkar barang & Rp.4.500.000 & Rp.5.400.000 & Rp.6.000.000 \\
& Total & Rp. 8.100.000 & Rp. 9.600.000 & Rp.11.448.000 \\
\hline
\end{tabular}

Sumber : PT. Aneka Usaha, 2017, 2018 dan 2019

Tabel 2. Biaya penyimpanan

\begin{tabular}{lllll}
\hline No & Jenis Biaya & Keterangan & & \\
& Jumlah & & & \\
\hline 1 & Biaya tenaga pengawa & Rp.1.000.000 & $\mathrm{x}$ & 12 \\
& Rp.12.000.000 & & \\
2 & Biaya listrik & Rp. 2.027 .000 & $\mathrm{x}$ & 12 \\
& Rp.24.324.000 & & & \\
3 & Biaya pemeliharaan & Rp.1.000.000 & $\mathrm{x}$ & 12 \\
& Rp.12.000.000 & & & \\
4 & PBB & & & \\
& Total & & & \\
& Rp.48.385.530 & & \\
\hline
\end{tabular}

Sumber : PT. Aneka Usaha, 2017, 2018 dan 2019

a. $\quad$ Rumus Biaya Pesan $=\frac{\text { Total Biaya Pesan }}{\text { Frekuensi Pemesanan }}$

Biaya Pesan tahun $2017=\frac{\text { Rp.8.100.000 }}{12}$ 


$$
=\text { Rp. } 675.000
$$

Biaya Pesan tahun $2018=\frac{\text { Rp.9.600.000 }}{12}$

Biaya Pesan tahun $2019=\frac{\text { Rp.11.448.000 }}{12}$

$$
=\text { Rp. } 800.000
$$

$$
=\text { Rp. } 954.000
$$

b. Rumus Biaya Simpan $=\frac{\text { Total Biaya Simpan }}{\text { Total Penjualan Produk }}$

Biaya Simpan per unit tahun $2017=\frac{\text { Rp.48.385.530 }}{27.268}=$ Rp. 1.774

Biaya Simpan per unit tahun $2018=\frac{\text { Rp.48.385.530 }}{33.066}=$ Rp. 1.463

Biaya Simpan per unit tahun 2019= $\frac{\text { Rp.48.385.530 }}{36.584}=$ Rp. 1.323

3) Jumlah Pembelian Optimal

\begin{tabular}{|c|c|c|c|c|}
\hline \multirow[t]{2}{*}{ No } & \multirow[t]{2}{*}{ Keterangan } & \multicolumn{3}{|c|}{ Tahun } \\
\hline & & 2017 & 2018 & 2019 \\
\hline 1. & Permintaan pertahun $(D)$ & $27.268 \mathrm{pcs}$ & $33.066 \mathrm{pcs}$ & $36.584 \mathrm{pcs}$ \\
\hline 2. & Biaya pesan $(S)$ & Rp.675.000 & Rp.800.000 & Rp.954.000 \\
\hline 3. & Biaya Simpan $(H)$ & Rp. 1.774 & Rp. 1.463 & Rp.1.323 \\
\hline
\end{tabular}

Tabel 3. Permintaan per tahun, biaya pesan dan biaya simpan 2017, 2018 dan 2019.

Rumus pembelian optimal adalah $=\frac{\sqrt{2 D S}}{H}$
a. $\quad E O Q$ tahun $2017=\frac{\sqrt{2 \times 27.268 \times 675.000}}{1.774}=4.555 \mathrm{pcs}$
b. $\quad E O Q$ tahun $2018=\frac{\sqrt{2 \times 33.066 \times 800.000}}{1.463}=6.013 \mathrm{pcs}$
c. $\quad$ EOQ tahun $2019=\frac{\sqrt{2 \times 36.584 \times 954.000}}{1.323}=7.265 \mathrm{pcs}$

4) Frekuensi pemesanan

Tabel 4. Frekuensi pembelian

\begin{tabular}{lllll}
\hline No & Keterangan & \multicolumn{2}{l}{ Tahun } & \\
\cline { 3 - 4 } & & 2017 & 2018 & 2019 \\
\hline
\end{tabular}


Vol. 1, No. 2, May 2020 e-ISSN: 2775-2496

https://journal-computing.org/index.php/journal-cisa/index

\begin{tabular}{lllll}
\hline 1 & Permintaan pertahun $(D)$ & 27.268 pcs & 33.066 pcs & 36.584 pcs \\
2 & EOQ & 4.555 pcs & 6.013 pcs & 7.265 pcs
\end{tabular}

Rumus frekuensi pembelian $=\frac{D}{E O Q}$

a. Frekuensi tahun $2017=\frac{27.268}{4.555}=6$ kali pembelian dalam 1 thn

b. Frekuensi tahun $2018=\frac{33.066}{6.013}=5$ kali pembelian dalam 1 thn

c. Frekuensi tahun $2019=\frac{36.584}{7.265}=5$ kali pembelian dalam 1 thn

5) Safety Stock

Tabel. 5. Pengaman persediaan

\begin{tabular}{lllll}
\hline No & Keterangan & Tahun & \\
\cline { 3 - 5 } & & 2017 & 2018 & 2019 \\
\hline 1 & Permintaan pertahun $(D)$ & $27.268 \mathrm{pcs}$ & $33.066 \mathrm{pcs}$ & $36.584 \mathrm{pcs}$ \\
2 & Hari Kerja & 269 hari & 269 hari & 269 hari \\
3 & Kebutuhan barang & 101 pcs & 123 pcs & 136 pcs \\
\hline
\end{tabular}

Rumus Safety Stock $=$ Kebutuhan barang perhari $(D \div$ Hari kerja $) \times L$ (waktu tunggu)

a. Safety Stock tahun $2017=101$ pcs $\times 6$ hari $=606$ pcs

b. Safety Stock tahun $2018=123$ pcs $\times 6$ hari $=738$ pcs

c. Safety Stock tahun $2019=136$ pcs $\times 6$ hari $=816$ pcs

6) Reorder Point

Tabel 6. Pemesanan kembali

\begin{tabular}{lllll}
\hline No & Keterangan & Tahun & & \\
\cline { 3 - 5 } & & 2017 & \multicolumn{1}{c}{2018} & 2019 \\
\hline 1 & Permintaan perhari $(d)$ & 101 pcs & 123 pcs & 136 pcs \\
2 & Waktu tunggu $(L)$ & 6 hari & 6 hari & 6 hari \\
3 & Persediaan Pengaman $(S S) 606$ pcs & 738 pcs & 816 pcs \\
\hline
\end{tabular}

Rumus Titik pemesanan kembali $=d x L_{+} S S$

a. Titik pemesanan kembali tahun $2017=101 \mathrm{pcs} \times$ 6 hari +738 pcs $=1.216$ pcs 
https://journal-computing.org/index.php/journal-cisa/index

b. Titik pemesanan kembali tahun $2018=123 \mathrm{pcs} \times$ 6 hari $+816 \mathrm{pcs}=1.475 \mathrm{pcs}$

c. Titik pemesanan kembali tahun $2019=136 \mathrm{pcs} \times$ 6 hari +816 pcs $=1.632$ pcs

7) Total Inventory Cost

Tabel 7. Total Biaya persediaan

\begin{tabular}{lllll}
\hline No Keterangan & \multicolumn{3}{l}{ Tahun } & \\
\cline { 3 - 5 } & & 2017 & 2018 & 2019 \\
\hline 1 & Permintaan pertahun $(D)$ & 27.268 pcs & 33.066 pcs & 36.584 pcs \\
2 & Biaya pesan $(S)$ & Rp.675.000 & Rp.800.000 & Rp.954.000 \\
3 & Biaya Simpan $(H)$ & Rp. 1.774 & Rp. 1.463 & Rp.1.323 \\
\hline
\end{tabular}

Rumus Total Inventory Cost $=\sqrt{2 \cdot D \cdot S \cdot H}$

a. Total Inventory Cost EOQ tahun $2017=\sqrt{2 \times 27.268 \times 675.000 \times 1.774}$

$=$ Rp. 8.082.108

b. Total Inventory Cost EOQ tahun $2018=\sqrt{2 \times 33.066 \times 800.000 \times 1.463}$

$=$ Rp. 8.798 .684

c. Total Inventory Cost EOQ tahun $2019=\sqrt{2 \times 36.584 \times 954.000 \times 1.323}$

$=$ Rp.9.608.308

8) Grafik Hubungan Antara EOQ, SS, dan ROP

a. Tahun 2017 


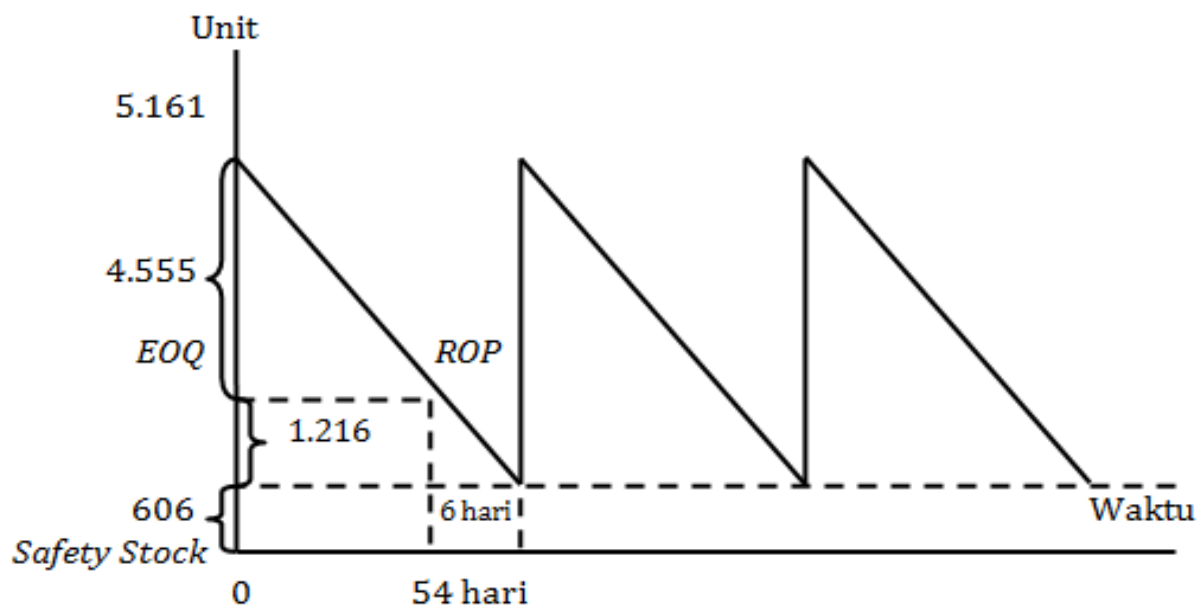

Gambar 5. Grafik hubungan antara EOQ, SS, dan ROP tahun 2017

b. Tahun 2018

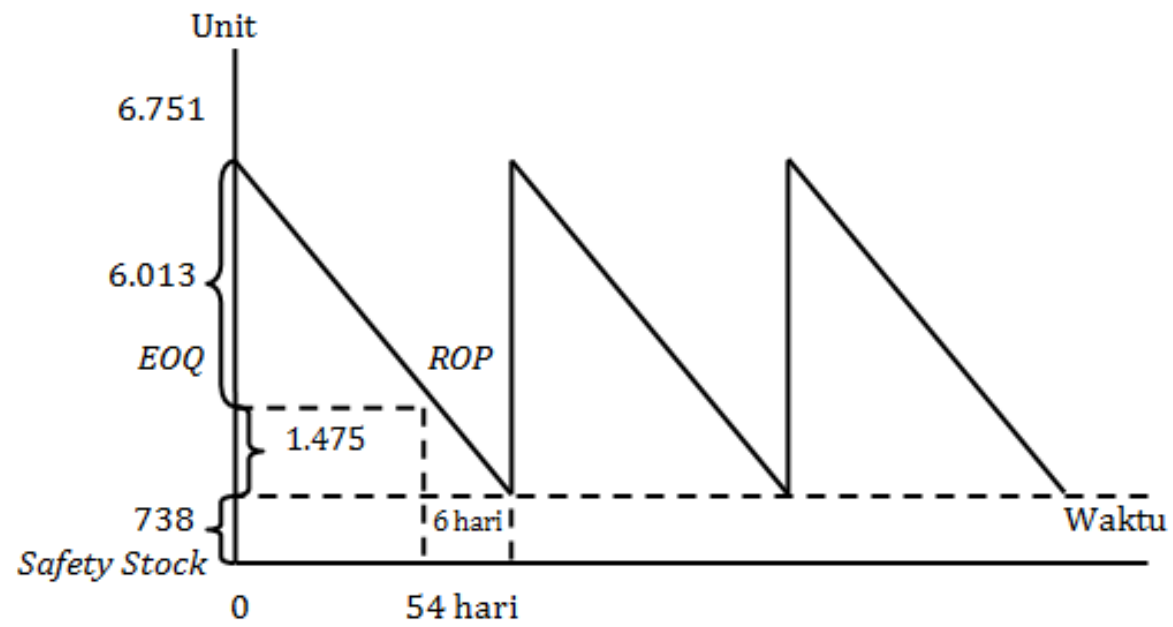

Gambar 6. Grafik hubungan antara EOQ, SS, dan ROP tahun 2018

c. Tahun 2019 
Vol. 1, No. 2, May 2020 e-ISSN: 2775-2496

https://journal-computing.org/index.php/journal-cisa/index

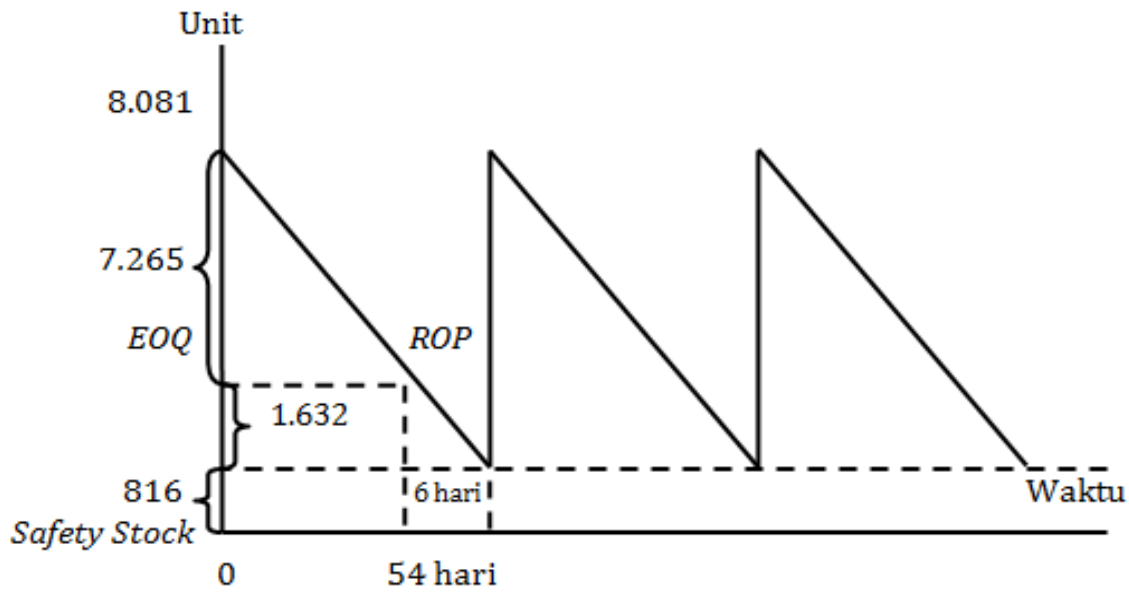

Gambar 7. Grafik hubungan antara EOQ, SS, dan ROP tahun 2019

\subsection{Pembahasan}

Hasil penelitian yang telah dilakukan mendapatkan hasil perbandingan yang disajikan dalam tabel berikut:

Tabel 8. Tabel hasil perbandingan dari data tahun 2017

\begin{tabular}{lllll}
\hline No & Keterangan & Kebijakan & Perusahaan & Metode $E O Q$ \\
\hline 1 & Jumlah pemesanan & $32.814 \mathrm{pcs}$ & $27.330 \mathrm{pcs}$ & $5.484 \mathrm{pcs}$ \\
2 & Frekuensi pemesanan & 12 kali & $6 \mathrm{kali}$ & $6 \mathrm{kali}$ \\
3 & Persediaan pengaman & Tidak ada & $606 \mathrm{pcs}$ & \\
4 & Titik pemesanan kembali & Barang hampir habis Sisa barang & $1.216 \mathrm{pcs}$ \\
5 & Persediaan maksimum & Tidak ada & 5.161 pcs & \\
6 & Total biaya persediaan & Rp.12.130.528 & Rp.8.082.108 & Rp.4.048.420 \\
\hline
\end{tabular}

Tabel 9. Tabel Hasil perbandingan dari data tahun 2018

\begin{tabular}{llll}
\hline No & Keterangan & Kebijakan Perusahaan & Metode $E O Q$ \\
\hline 1 & Jumlah pemesanan & $37.600 \mathrm{pcs}$ & $30.065 \mathrm{pcs}$ \\
2 & Frekuensi pemesanan12 kali & $5 \mathrm{kali}$ & $7 \mathrm{kali}$ \\
3 & Persediaan pengaman & Tidak ada & $738 \mathrm{pcs}$ \\
4 & Titik pemesanan kembali & Barang hampir habis & Sisa barang $1.475 \mathrm{pcs}$ \\
5 & Persediaan maksimum & Tidak ada & 6.751 pcs \\
6 & Total biaya persediaan & Rp.13.632.028 & Rp.8.798.684 \\
\hline
\end{tabular}

Tabel 10. Tabel Hasil perbandingan dari data tahun 2019

No Keterangan Kebijakan Perusahaan Metode EOQ


Vol. 1, No. 2, May 2020 e-ISSN: 2775-2496

https://journal-computing.org/index.php/journal-cisa/index

\begin{tabular}{llll}
\hline 1 & Jumlah pemesanan & 45.600 pcs & 36.325 pcs \\
2 & Frekuensi pemesanan & 12 kali 5 kali & 7 kali \\
3 & Persediaan pengaman & Tidak ada & 816 pcs \\
4 & Titik pemesanan kembali & Barang hampir habis & Sisabarang 1.623 pcs \\
5 & Persediaan maksimum & Tidak ada & 8.081 pcs \\
6 & Total biaya persediaan & Rp.16.473.831 & Rp.9.608.308 \\
\hline
\end{tabular}

Perhitungan menggunakan metode $E O Q$ yang telah dilakukan ini membuktikan bahwa metode $E O Q$ memiliki lebih banyak keuntungan dengan terlihatnya penghematan biaya yang dihasilkan. Untuk persentase perbandingan margin dapat dilihat pada tabel berikut:

Tabel 11. Tabel hasil perbandingan margin biaya persediaan dengan kebijakan perusahaan dan margin dengan metode $E O Q$

\begin{tabular}{lcc}
\hline \multirow{2}{*}{ Keterangan } & Tahun & \\
\cline { 2 - 3 } & 2017 & 2018 \\
\hline Total cost & Rp.158.831.174 & Rp.202.504.063 \\
TIC perusahaan & Rp.12.130.528 & Rp.13.632.028 \\
TIC EOQ & Rp.8.082.108 & Rp.8.798.684 \\
Margin perusahaan & $7,6 \%$ & $6,7 \%$ \\
Margin EOQ & $5 \%$ & $4,3 \%$ \\
\hline
\end{tabular}

Persentase margin didapatkan dari membagi TIC dengan Total Cost kemudian dikalikan 100. Margin biaya persediaan tersebut adalah biaya yang dikeluarkan perusahaan untuk persediaan barang. Dari perhitungan yag telah dilakukan diketahui hasil margin dengan metode EOQ didapatkan lebih rendah jika dibandingkan dengan margin biaya yang telah dikeluarkan oleh perusahaan selama ini.

\section{CONCLUSION}

Dari hasil penelitian dan pembahasan yang telah dilakukan pada bab sebelumnya , dapat ditarik suatu kesimpulan sebagai berikut:

1) Frekuensi pemesanan yang sebelumnya dilakukan PT. Aneka Usaha adalah sebanyak 12 kali pemesanan dalam satu tahun dengan jumlah pemesanannya hanya diperkirakan tanpa metode, sedangkan menggunakan metode EOQ frekuensi pemesanan hanya sebanyak 5 kali .

2) Didapatkan persediaan pengaman yang harus selalu tersedia di gudang adalah sebanyak 606 pcs untuk tahun 2017,738 untuk tahun 2018 dan 816 pcs untuk tahun 2019, persediaan pengaman 
https://journal-computing.org/index.php/journal-cisa/index

ini berfungsi untuk menghindari jika sewaktu-waktu gudang kekurangan stock.

3) Untuk tahun 2017 titik pemesanan kembali dilakukan saat barang dalam gudang tersisa sebesar 1.216 pcs, tahun 2018 saat barang tersisa 1.475 pcs dan tahun 2019 saat barang tersisa 1.632 pcs .

4) Total biaya persediaan menggunakan metode EOQ sebesar Rp.8.082.108 untuk tahun 2017, Rp.8.798.684 untuk tahun 2018 dan Rp.9.609.808 untuk tahun 2019, ini menunjukkan adanya penurunan total biaya jika dibandingkan dengan yang dikeluarkan PT. Aneka Usaha sebelumnya.

\section{DAFTAR PUSTAKA}

[1] Ryan, "Pengertian, Fungsi, dan Metode Pengendalian Persediaan (Stock Control) pada Perusahaan Manufaktur _ Software ERP Bisnis Ukirama.html," Apr 16, 2018. https://ukirama.com/blogs/pengertian-fungsi-dan-metodepengendalian-persediaan-stock-control-pada-perusahaanmanufaktur.

[2] Musthafa, Manajemen Keuangan. Penerbit Andi, 2017.

[3] Yuwono dan Abdullah, "2013100208MNBab2001 - page 8 of 10," 2013.

https://library.binus.ac.id/eColls/eThesisdoc/Bab2HTML/20131 00208MNBab2001/page8.html (diakses Nov 17, 2019).

[4] F. Margaretha, Teori dan Aplikasi Manajemen Keuangan Investasi dan Sumber Dana Jangka Pendek. Grasindo, 2005.

[5] J. Heizer dan B. Render, Manajemen Operasi Manajemen Keberlangsungan dan Rantai Pasokan, Edisi 11. Jakarta Selatan: Salemba Empat, 2015.

[6] I. N. Pujawan dan Mahendrawathi, Supply Chain Management, Edisi 3. Yogyakarta: Penerbit Andi, 2017.

[7] S. Arikunto, Prosedur Penelitian. Yogyakarta: Rineka Cipta, 2010. 